Original Research Paper

\title{
Effect of Composted Animal Manure as Fertilizer on Productivity of Azolla Pinnata Grown in Earthen Ponds
}

\author{
Ristianto Utomo, Cuk Tri Noviandi, Nafiatul Umami, and Adhitya Permadi \\ Laboratory of Feed Technology, Department of Animal Nutrition and Feed Science, \\ Faculty of Animal Science, Universitas Gadjah Mada, Yogyakarta, Indonesia
}

\author{
Article history \\ Received: 18-06-2019 \\ Revised: 09-10-2019 \\ Accepted: 07-11-2019 \\ Corresponding Author: \\ Cuk Tri Noviandi \\ Laboratory of Feed \\ Technology, Department of \\ Animal Nutrition and Feed \\ Science, Faculty of Animal \\ Science, Universitas Gadjah \\ Mada, Yogyakarta, Indonesia \\ Email: c.t.noviandi@ugm.ac.id
}

\begin{abstract}
Azolla pinnata contains a high nutritional value with a high protein content of $25 \%$, so it can be used as an alternative to animal feed. The low production of Azolla is caused by the suboptimal use of fertilizers. This study aims were to determine the type of manure (composted manure from poultry, goats, and rabbit) which was the most optimal in producing Azolla. Azolla pinnata was planted at $50 \times 50 \times 10 \mathrm{~cm}(\mathrm{~W} \times \mathrm{L} \times \mathrm{H})$ soil pools coated with plastic sheets. To maintain the acidity of the media, $10 \%(2 \mathrm{~kg})$ of sludge fields was added to each pond. Water and animal waste compost $(5 \mathrm{~g} / \mathrm{L})$ were added to each pond as a treatment. The treatments were: paddy mud (K0), paddy mud + poultry composts (K1), paddy mud + compost rabbit manure (K2) and paddy mud + compost goat manure (K3). Each treatment was repeated 5 times. Measurements made were $\mathrm{pH}$ of the media, area of cover, yield ( $g$ weight of dry matter) and crude protein content of Azolla. Harvesting was done every 14 days. The results showed that the Azolla dry matter production of $\mathrm{K} 1, \mathrm{~K} 2$ and $\mathrm{K} 3$ treatments were greater ( $\mathrm{p}<0.01)$ than K0 $\left(20.80,18.20\right.$, and 19.00 vs. $10.40 \mathrm{~g} / 2,500 \mathrm{~cm}^{2}$; respectively). Among the compost treatments, the crude protein content of $\mathrm{K} 1$ and $\mathrm{K} 2$ were higher than K0 and K3 (25.34 and 26.25 vs. 13.11 and $22.96 \%$, respectively; $\mathrm{p}<0.01$ ). Fertilizing with rabbit or poultry compost was the best in improving Azolla production and crude protein content.
\end{abstract}

Keywords: Organic Fertilizer, Animal Manures, Azolla Production, Crude Protein

\section{Introduction}

Azolla pinnata is a water fern plant that is potentially an alternative source of protein and minerals for livestock. Azolla pinnata has many benefits such as bio fertilizer, human food (Pabby et al., 2003), animal feed, fish feed and as medicinal supplements (Jain et al., 1992). Its protein content ranges from 21.4 - 37\% (Alalade and Iyayi, 2006), with a protein digestibility of $84 \%$, highly of total crude protein so it is potentially used as a protein supplement for livestock (Parashumaluru et al., 2013). Azolla pinnata has a short production cycle, with harvesting time of $7-20$ days and fresh biomass production can reach up to 390 tons/ha/year (Ferentinos et al., 2002). Azolla pinnata has many benefits such as bio fertilizer, human food, animal and fish feed, as well as medicinal supplements (Mithraja et al., 2011). The use of animal manure as fertilizer for Azolla pinnata will reduce the costs of production but the type and rate of application of manure is still not known. However, there were few studies related to the right fertilizer for optimizing the growth of Azolla pinnata. In addition, most studies on Azolla's chemical composition and/or feeding values have not used Azolla biomass obtained from productive cultures, or not report biomass productivity data of analyzed plants.

The use of organic fertilizers in this study was performed due to organic fertilizers have advantages over inorganic fertilizers, including improving soil structure, adding nutrients, increasing nutrients and organic materials, improving the life of microorganisms. In addition, the nutrient content in organic fertilizer is released slowly so that it can benefit the plant (Samadi and Cahyono, 2005). The objectives of this study were to establish the type of compost used and the time of harvest for optimal growth and production of Azolla pinnata grown under earthen 
ponds. The composts used in this study were manure from poultry, rabbits, and goats.

\section{Materials and Methods}

\section{Preparation of Ponds and Treatments}

Twenty ponds were randomly divided into four treatment groups based on type of organic fertilizer used (compost made from poultry, rabbit and goat manure) to fertilize the water in the ponds. The treatments were: Control (K0) without compost addition, K1 (chicken excreta compost), K2 (rabbit feces compost) and K3 (goat feces compost). Each treatment consisted of five replicates. The basal media used were water with the addition of $10 \%$ mud $(2 \mathrm{~kg})$ obtained from paddy fields situated in the vicinity of the university. The media (with the respective fertilizer compost) were prepared and allowed to stand in the ponds for 7 days (to dissolve the fertilizer) before the inoculation of Azolla. Fresh Azolla pinnata (about $10 \mathrm{~g}$ fresh weight), were disinfected using potassium permanganate at $20 \mathrm{ppm}$ for $60 \mathrm{~min}$ (Arizal, 2010) before inoculation onto the media. The experiment lasted for 42 days and the Azolla was harvested every 14 days (Ferentinos et al., 2002). Weekly measurements and samples taken were $\mathrm{pH}$ of water, area of water covered by Azolla (cover area), yield (dry matter), and crude protein of Azolla pinnata.

\section{Measurements of $\mathrm{pH}$, Crude Protein and Cover Area}

Determination of $\mathrm{pH}$ was carried out by using $\mathrm{pH}-$ meter (Hannah). Determination of protein content was performed using the Kjeldahl method (AOAC, 2005). Cover area of Azolla pinnata was measured weekly using $60 \mathrm{~cm}$ ruler by measuring the length and width of the water surface covered by Azolla pinnata. Kinetics of dry matter production were determined by calculating the production of Azolla pinnata at every harvest The kinetics of production was carried out to find out the exact time for fertilization to be seen from the production of Azolla pinnata which has dropped dramatically. Production in forecast was done to determine the estimated production of Azolla pinnata for 5 weeks ( 4 weeks of production +1 week of rest).

\section{Statistical Analysis}

All data were analyzed using Statistical Analysis System (SAS) software using the model described below:

$$
Y_{i j}=\mu+\tau_{i}+\varepsilon_{i j}
$$

where, $Y_{i j}$ is the Azolla response variable measured, $\mu$ is the overall mean. $\tau$ is the fixed effect of fertilizer and $\varepsilon$ is the error. The differences between the means were compared using Duncan's new multiple range test.

\section{Result}

Water $p H$

The $\mathrm{pH}$ of water in the ponds was measured for each pond on the different treatments and the means are shown in Table 1. The results showed that the average $\mathrm{pH}$ of water in ponds on treatment $\mathrm{K} 0$ day 7 and at day 14 , were similar to the $\mathrm{pH}$ at day 0 , suggesting that with any fertilization the alkalinity of the water tended to stabilized over time. This finding suggested that treatment with chicken manure as well as rabbit and goat feces compost stabilize the alkalinity of the water.

\section{Cover Areas}

The cover areas of the Azolla pinnata in each pond were obtained by measuring the area of Azolla pinnata per $2,500 \mathrm{~cm}^{2}$ on the surface of the ponds using a ruler. The results of the measurement of the cover area are shown in Table 2. The cover area of Azolla in ponds for all fertilizer treatments was similar until Day 7, but on Day 14 the cover area of all fertilizer treatments were higher than those of the control, suggesting that fertilizer treatment increased the growth of Azolla after 14 days.

\section{Production and Protein Content of Azolla pinnata}

Production and crude protein content of Azolla pinnata with several kinds of fertilizer use can be seen in Table 3. The growth of Azolla pinnata was influenced by the amount of nutrient element dissolved in water especially element phosphorus (P). Chicken excreta and goat feces contain $\mathrm{P}$ which is sufficiently high for Azolla (3 and 2.46\%, respectively) with production of Azolla pinnata 12.40 and $11.20 \mathrm{~g} / 2,500 \mathrm{~cm}^{2}$, respectively.

\section{Kinetics Production}

Azolla pinnata was harvested after the plant was two weeks old (fourteen days). The harvesting kinetic every fourteen days is listed in Table 4. There were a decrease in production of dry matter during the second and the third 14 days periods when the ponds were not fertilized after the initial fertilization. However the decline in production were more dramatic during the $3^{\text {rd }}$ m 14-day period, suggesting that after the second 14 days harvest the ponds need to be fertilized to maintain the high production. The reduction dry matter production could be due to the lowering of available nutrients, especially phosphorus, for the Azolla and possibly the decline in $\mathrm{pH}$. 
Table 1: The $\mathrm{pH}$ of water in the treatment ponds, measured at 0,7 , and 14 days of growth period

\begin{tabular}{llll}
\hline Type of fertilizer & First day & Seventh day & Fourteenth day \\
\hline Mud only (control / K0) & $8.98 \pm 0.29$ & $8.89 \pm 0.33$ & $8.81 \pm 0.27$ \\
K1 (chicken excreta compost) & $8.14 \pm 0.39$ & $8.59 \pm 0.43$ & $9.54 \pm 0.98$ \\
K2 (rabbit feces compost) & $8.08 \pm 0.24$ & $8.46 \pm 0.21$ & $8.82 \pm 0.35$ \\
K3 (goat feces compost) & $8.54 \pm 0.20$ & $8.77 \pm 0.26$ & $8.68 \pm 0.27$ \\
\hline
\end{tabular}

Table 2: Cover area $\left(\mathrm{cm}^{2}\right)$ of Azolla pinnata measured at 7 and 14 days of growth period

\begin{tabular}{|c|c|c|c|}
\hline \multirow[b]{2}{*}{ Type of fertilizer } & \multicolumn{3}{|c|}{ Cover area (per 2,500 $\mathrm{cm}^{2}$ ) } \\
\hline & Day 0 & Day 7 & Day 14 \\
\hline Mud only (control/K0) & $338.6 \pm 19.99$ & $750 \pm 36.74$ & $1,320^{\mathrm{a}} \pm 270.65$ \\
\hline K1 (chicken excreta compost) & $320.4 \pm 19.72$ & $1,696 \pm 862.69$ & $2,500^{\mathrm{b}} \pm 0$ \\
\hline K2 (compost of rabbit feces) & $338.6 \pm 19.99$ & $1,465 \pm 348.93$ & $2,500^{\mathrm{b}} \pm 0$ \\
\hline K3 (goat feces compost) & $338.6 \pm 19.99$ & $1,560 \pm 210.36$ & $2,500^{\mathrm{b}} \pm 0$ \\
\hline
\end{tabular}

Table 3: Production and crude protein content of Azolla pinnata at 7 days of growth period

\begin{tabular}{lll}
\hline Type of fertilizer & $\begin{array}{l}\text { Dry weight of Azolla pinnata } \\
\text { per } 2.500 \mathrm{~cm}^{2}(\mathrm{~g})\end{array}$ & $\begin{array}{l}\text { The average crude protein } \\
\text { content of Azolla pinnata }(\%)\end{array}$ \\
\hline Control (no fertilizer) (K0) & $9.60^{\mathrm{a}} \pm 1.52$ & $13.11^{\mathrm{a}} \pm 0.52$ \\
K1 (chicken excreta compost) & $11.20^{\mathrm{bc}} \pm 0.84$ & $25.34^{\mathrm{c}} \pm 0.89$ \\
K2 (compost of rabbit fecal) & $9.40^{\mathrm{a}} \pm 0.55$ & $26.25^{\mathrm{c}} \pm 1.23$ \\
K3 (goat fecal compost) & $12.40^{\mathrm{c}} \pm 1.67$ & $22.96^{\mathrm{b}} \pm 1.46$ \\
\hline
\end{tabular}

abc Means with different superscript within the same column are significantly different $(\mathrm{p}<0.01)$.

Table 4: Production of Azolla pinnata harvested every 14 days (g DM) over a period of 42 days

\begin{tabular}{lllll} 
Type of fertilizer & P1 (The first 14 days) & P2 (The second 14 days) & P3 (The third 14 days) & Mean \\
\hline Mud (control / K0) & $9.60 \pm 1.52$ & $0.80 \pm 0.45$ & $0.38 \pm 0.23$ & $3.59^{\mathrm{a}} \pm 0.73$ \\
K1 (K0 + chicken excreta compost) & $11.20 \pm 0.84$ & $9.60 \pm 1.82$ & $2.86 \pm 1.17$ & $7.89^{\mathrm{c}} \pm 1.28$ \\
K2 (K0 + compost of rabbit feces) & $9.40 \pm 0.55$ & $9.60 \pm 1.14$ & $2.46 \pm 0.44$ & $7.15^{\mathrm{bc}} \pm 0.71$ \\
K3 (K0 + goat feces compost) & $12.40 \pm 1.67$ & $5.80 \pm 1.64$ & $1.06 \pm 0.53$ & $6.42^{\mathrm{b}} \pm 1.28$ \\
Mean & $10.65^{\mathrm{c}} \pm 1.15$ & $6.45^{\mathrm{b}} \pm 1.26$ & $1.69^{\mathrm{a}} \pm 0.59$ & \\
\hline
\end{tabular}

$\overline{a b c}$ Means with different superscript within same column are significantly different $(\mathrm{p}<0.01)$

Table 5: The total dry matter production of Azolla pinnata (g DM), over a period of 4 weeks (5 weeks production cycle)

\begin{tabular}{lllll}
\hline Type of fertilizer & P1 (The first 14 days) & P2 (The second 14 days) & Total production per 28 days & Mean \\
\hline Mud (control/K0) & $9.60 \pm 1.52$ & $0.80 \pm 0.45$ & $10.40 \pm 1.05$ & $5.20^{\mathrm{a}} \pm 1.01$ \\
K1 (chicken excreta compost) & $11.20 \pm 0.84$ & $9.60 \pm 1.82$ & $20.80 \pm 0.99$ & $10.40^{\mathrm{c}} \pm 1.22$ \\
K2 (compost of rabbit fecal) & $9.40 \pm 0.55$ & $9.60 \pm 1.14$ & $20.00 \pm 1.04$ & $9.50^{\mathrm{bc}} \pm 0.91$ \\
K3 (goat fecal compost) & $12.40 \pm 1.67$ & $5.80 \pm 1.64$ & $18.20 \pm 1.59$ & $9.10^{\mathrm{b}} \pm 1.63$ \\
Mean & $10.45 \pm 1.15$ & $6.45 \pm 1.27$ & $16.90 \pm 1.17$ & \\
\hline
\end{tabular}

abc Means with different superscript within same column are significantly different $(\mathrm{p}<0.01)$

\section{Production in Forecast}

It was proposed that Azolla must be harvested after 14 days ( 2 weeks) inoculation and then it need to be fertilized to maintain its high production. It is suggested that each production period consists of 5 weeks $((2 \times 2$ weeks of harvest) +1 week of fertilization). The calculated amount of dry matter production per 5 weeks (including 1 week standing after fertilization) cycle is shown in Table 5.

\section{Discussion}

The increase in $\mathrm{pH}$ that has been observed shows that in all various sources of fertilizer produces a different $\mathrm{pH}$ after 1 week, an increase in $\mathrm{pH}$ occurs on day $7^{\text {th }}$ and $14^{\text {th }}$. The $\mathrm{pH}$ value of media is an indicator of chemical fertility as a result of the nitrification and denitrification process by ponds water bacteria derived from manure that can produce $\mathrm{OH}^{-}$subsequently increasing the $\mathrm{pH}$ of pond 1 water (Akhmar, 2007). Azolla pinnata can live at a $\mathrm{pH}$ of 3.5 to 10 , but in water which is too acid there will be an adverse effect on growth. The $\mathrm{pH}$ of the water where Azolla was recorded ranged from 7.1 to $9.0($ mean $=7.8)($ Serag et al., 2000).

Based on the two weekly observations made, it appeared that the $\mathrm{pH}$ of ponds water given compost (chicken excreta, rabbit feces, and goat feces) were higher compared to that of ponds that were not given compost. The decomposition process of organic material 
found in compost by microorganisms will also produce $\mathrm{OH}^{-}$ions thus increasing the $\mathrm{pH}$ value in the pods water (Sawyer and Mc Carty, 1998). The higher pH of ponds water was probably due to the increased photosynthetic process by Azolla pinnata so that $\mathrm{CO}_{2}$ was converted into $\mathrm{C}_{6} \mathrm{H}_{12} \mathrm{O}_{6}$ which requires energy and hydrogen input. Energy is obtained from sunlight while hydrogen $\left(\mathrm{H}^{+}\right.$ ion) is obtained from ponds water, removing $\mathrm{H}^{+}$ions from ponds water can increase water $\mathrm{pH}$ (Hasan and Chakrabarti, 2009). All of the ponds used in this study had $\mathrm{pH}$ which is ideal for the growth of Azolla pinnata. In their study, Hasan and Chakrabarti (2009) showed that Azolla pinnata can live on $\mathrm{pH} 3.5$ to 10 .

The increase in the area cover, as a result of the fertilization process carried out is greater than the control. The availability of nutrients in the form of phosphate in planting medium can affect the growth of Azolla pinnata, because this plant efficiently absorbs phosphorus (P) early in the beginning of their growth (Lumpkin and Plucknett, 1982).

Insufficient concentration of phosphate can inhibit growth rate, nitrogen fixation and chlorophyll content in Azolla pinnata. The content of nutrients in chicken manure is known to be three times larger than other livestock manure because chicken manure is mixed with feces and urine (excreta) so that chicken manure has a nitrogen content ranging from 1.00 to $3.13 \%$, in addition to phosphorus $\left(\mathrm{P}_{2} \mathrm{O}_{5}\right)$ which range between 2.80 to $6.00 \%$ (Marschner, 1986). The high phosphorus content can increase Azolla growth.

Production of Azolla pinnata influenced by the $\mathrm{P}$ content contained in fertilizer. According to Lumpkin and Plucknett (1982), Azolla pinnata plants can grow rapidly because these plants can efficiently absorb $\mathrm{P}$ elements from the beginning of its growth.

The highest dry matter production of Azolla pinnata was obtained from the ponds on K3 treatment, which was $12.40 \pm 1.67 \mathrm{~g}$ and the lowest was from K2 treatment, which was not significantly different from that of the control (K0). Further test results showed that dry weight yield between treatments $\mathrm{K} 1$ and $\mathrm{K} 3$ showed no significant differences. According to Marschner (1986), the phosphorus element is influential in increasing the dry weight of plants to form the required pyrophosphate compounds as the main source of energy for plant growth and development. Element $\mathrm{P}$ is also used as a constituent of phospholipids for cell membrane structures.

The production of Azolla per ha per year can be projected as follows: After two harvests $(2 \times 14$ days $)$, the dry matter production will start to decline, therefore the ponds need to be fertilized again, followed by rest for 7 days, hence, it takes 5 weeks per cycle. In one year there are 52 weeks of which means that it is possible to run 10 cycles of harvest, with an annual production of 83.2 tones/ha/year $\left(20.80 \mathrm{~g}\right.$ dry matter/2,500 $\mathrm{cm}^{2}$, production $=(100,000,000: 2,500) \times 20.80 \mathrm{~g} \times 10=83,200 \mathrm{~kg} / \mathrm{ha} / \mathrm{yr})$.

\section{Conclusion}

It can be concluded that organic fertilizer both chicken feces compost and rabbit feces compost when used as fertilizer in ponds of Azolla, with an estimated production of more than $20 \mathrm{~g} \mathrm{BK} / 2,500 \mathrm{~cm}^{2}$ per 5 weeks or projected as $83,200 \mathrm{~kg} / \mathrm{ha} /$ year) and higher protein content compared to fertilization with goat feces compost. It was proposed that each production cycle consisted of 5 weeks period, with 1 week rest after fertilizer application followed by two 2 weeks growth period.

\section{Acknowledgement}

The research team expressed our gratitude and appreciation for funding support of this research to Masters Study Program in the Faculty of Animal Science, Universitas Gadjah Mada, Yogyakarta, Indonesia.

\section{Funding Information}

This manuscript is funded by the Masters Study Program in the Faculty of Animal Science, Universitas Gadjah Mada, Yogyakarta, Indonesia.

\section{Author's Contributions}

Ristianto Utomo: Coordinated the implementation of research work, conducted research, compiled the literary review, analyzed and interpreted the study findings, drew conclusions, contributed manuscript preparation and revisions main supervisor for Mr. Permadi.

Cuk Tri Noviandi: Contribution Second researcher, designed the research plan, organized the study, conducted research and contributed to result analysis and the writing manuscript, co-supervisor for Mr. Permadi.

Nafiatul Umami: Conducted research, compiled the literary review, analyzed and interpreted the results, contributed manuscript revisions, Third researcher, cosupervisor for Mr. Permadi.

Adhitya Permadi: Conducted research, contributed manuscript revisions.

\section{Ethics}

This article is original and contains unpublished material. The corresponding author confirms that all of the other authors have read and approved the manuscript and there are no ethical issues involved

\section{References}

Akhmar, M.F., 2007. Pengaruh kepadatan Azolla pinnata terhadap kualitas fisik dan kimia limbah cair pabrik tahu di Desa Bocek Kecamatan Karangploso Kabupaten Malango Thesis. UIN Malang. 
Alalade, O.A. and E.A. Iyayi, 2006. Chemical composition and the feeding value of Azolla (Azolla pinnata) meal for egg-type chicks. Int. J. Poultry Sci., 5: 137-141. DOI: 10.3923/ijps.2006.137.141

AOAC, 2005. Offcial Method of Analysis. 18th Edn., The Association of Offecial Analytical Chemist, Wasington DC.

Arizal, A., 2010. Kandungan nitrogen (N) pada Azolla pinnata yang ditumbuhkan dalam media air dengan kadar $\mathrm{P}$ yang berbeda. Institute Pertanian Bogor.

Ferentinos, L., J. Smith and H. Venezuela, 2002. Green manure corp: Azolla. Sus. Agri SA-GM-2, Hawai.

Hasan, M.R. and R. Chakrabarti, 2009. Use of algae and aquatic macrophytes as feed in small-scale aquaculture. Food and Agriculture Organization of the United Nations, Rome.

Jain, S.K., G.S. Gujral, N.K. Jha and P. Vasudevan, 1992. Production of biogas from Azolla pinnata R. $\mathrm{Br}$ and Lemna minor L.: Effect of heavy metal contamination. Biores. Technol., 41: 273-277. DOI: 10.1016/0960-8524(92)90013-N

Lumpkin, T.A. and D.L. Plucknett, 1982. Azolla as a green manure: Use and management in crop production. Westview Press, Boulder, Colorado.
Marschner, H., 1986. Mineral Nutrition of Higher Plants. 3rd Edn., Academic Press, London.

Mithraja, M.J., M. Johnson, M. Mahesh, Z.M. Paul and S. Jeeva, 2011. Phytochemical studies on Azolla pinnata R. Br., Marsilea minuta L. and Salvinia molesta Mitch. Asian Pacific J. Tropical Biomed., 1: 26-29. DOI: 10.1016/S2221-1691(11)60116-0

Pabby, A., R. Prasanna and P.K. Singh, 2003. AzollaAnabaena symbiosis-from traditional agriculture to biotechnology. Indian J. Biotechnol., 2: 26-37.

Parashumaluru, S., P. Swain and D. Nagalakshmi, 2013. Protein fractionation and in vitro digestibility of Azolla in ruminants. Online J. Anim. Feed Res., 3: 129-132.

Samadi, B. and B. Cahyono, 2005. Bawang merah intensifikasi usaha tani. Kanisius, Yogyakarta.

Sawyer, C.N. and P.L. Mc Carty, 1998. Chemistry for Sanitary Engineering. 2nd Edn., Mc Graw Hill, New York.

Serag, M.S., A. El-Hakeem, A. Badway and M.A. Mousa, 2000. On the Ecology of Azolla filiculoides. Limnologica, 30: 73-81.

DOI: $10.1016 / \mathrm{S} 0075-9511(00) 80047-X$ 